\title{
PENGAWASAN KINERJA ADVOKAT DALAM PEMBERIAN BANTUAN DAN PELAYANAN JASA HUKUM (Studi di Jawa Tengah)*
}

\author{
Agus Raharjo, Angkasa, dan Hibnu Nugroho \\ Fakultas Hukum Universitas Jenderal Soedirma \\ E-mail: agus.raharjo007@gmail.com
}

\begin{abstract}
The advocate performance is simply defined as effectiveness of services provided by advocates and efficiency of allocated resources to prepare such services. There are several reasons that make the effectiveness of the advocate performance cannot be determined exactly. This research, accordingly, tries to find out the causes by applying empirical legal methods through sociological and economics approach. The indicators of performance can be classified into several types, namely efficiency, effectiveness, cost-effectiveness and impact indicators. Based on the results of a study of lawyers, law firm/law office or legal aid organizations in Central Java, a performance indicator has not been fully and consistently implemented. They have not implemented a process-oriented quality manage-ment as an end result of legal services. Then, orientation still focused on the win-lose principle in handling criminal cases, and ignored management principles. Moreover, transparency as a prerequisite of performance measurement is not easily achieved. This happens because the supervision of the work and their performance is still very weak.
\end{abstract}

Keywords: advocate, performance, legal services, legal aid

\begin{abstract}
Abstrak
Kinerja advokat secara sederhana didefinisikan sebagai efektivitas jasa yang disediakan oleh advokat dan efisiensi sumberdaya yang dialokasikan dan digunakan untuk menyiapkan jasa tersebut. Ada beberapa sebab yang menjadikan efektivitas kinerja advokat tidak dapat ditentukan secara eksak. Penelitian yang berupaya mencari dan menemukan sebab-sebab itu menggunakan metode penelitian hukum empiris dengan pendekatan sosiologis dan ilmu ekonomi. Indikator kinerja dapat digolongkan menjadi beberapa jenis, yaitu indikator efisiensi, efektivitas, efektivitas biaya dan dampak. Berdasarkan hasil penelitian terhadap advokat, kantor hukum/law office maupun lembagan bantuan hukum di Jawa Tengah, indikator kinerja di atas belum diterapkan secara menyeluruh dan konsisten. Mereka belum menerapkan proses manajemen yang berorientasi pada mutu sebagai suatu hasil akhir dari pelayanan jasa hukum. Orientasi masih menitikberatkan pada prinsip menang-kalah dalam penanganan perkara pidana, dan prinsip-prinsip manajemen diabaikan. Transparansi sebagai salah satu prasyarat pengukuran kinerja juga sulit diperoleh. Hal ini terjadi karena pengawasan terhadap kerja dan kinerja mereka masih sangat lemah.
\end{abstract}

Kata kunci: advokat, kinerja, jasa hukum, bantuan hukum

\section{Pendahuluan}

Bidang pekerjaan advokat adalah memberikan jasa hukum atau bantuan hukum bagi masyarakat yang membutuhkannya. Tentu saja pemberian bantuan hukum oleh advokat dalam kerangka yang lebih besar ditujukan untuk memenuhi tujuan hukum, yaitu keadilan, ${ }^{1}$ keman-

\footnotetext{
- Artikel ini merupakan artikel hasil penelitian Hibah
} Kompetensi 2013 yang dibiayai oleh DP2M DIKTI Kemen- faatan, kepastian, keteraturan, penyeimbang berbagai kepentingan, ${ }^{2}$ kesejahteraan, dan ke-

terian Pendidikan dan Kebudayaan sesuai dengan Surat Perjanjian Pelaksanaan Penugasan Penelitian No. 017/ SP2H/PL/DIT.LITABMAS/V/2013 tanggal 13 Mei 2013

1 Lihat dan bandingkan dengan Zudan Arif Fakrulloh, "Penegakan Hukum sebagai Peluang Menciptakan Keadilan". Jurisprudence, Vol. 2 No. 1 Maret 2005.

2 Bandingkan dengan pendapat Pekuwali pada Umbu Lily Pekuwali, "Memposisikan Hukum sebagai Penyeim-bang Kepentingan Masyarakat", Jurnal Hukum Pro Jus-titia Vol. 26 No. 4 Oktober 2008, Bandung: FH UNPAR. 
bahagiaan. ${ }^{3}$ Mengingat tugas dan fungsi advokat yang demikian, advokat dapat berperan ganda, yaitu sebagai saluran untuk melahirkan korupsi, tetapi juga dapat sebagai individu yang dapat memberantas korupsi.

Apabila mengacu kepada Pasal 5 UU No. 18 Tahun 2003 tentang Advokat, maka sesungguhnya kedudukan dan status advokat sudah sangat jelas, yaitu sebagai penegak hukum yang bebas dan mandiri, dijamin oleh hukum dan peraturan perundang-undangan. ${ }^{4}$ Sebagai penegak hukum, advokat memiliki kedudukan yang sama dengan hakim, yaitu mandiri, independen, dan bebas. Kedudukan yang sedemikian tak menyebabkan advokat memiliki kekuasaan yang sama dengan penegak hukum lain. Advokat tidak punya kekuasaan seperti penegak hukum lain, meski dari segi luas atau jangkauan pekerjaan sebenarnya lebih luas dibandingkan dengan penegak hukum lain. Advokat bertugas dari hulu ke hilir, dari tingkat penyidikan sampai jatuhnya putusan pengadilan dan jalannya pemidanaan. Penegak hukum lain bersifat parsial, tidak bisa turut campur pada setiap tingkat peradilan, polisi hanya melakukan penyelidikan, tidak melakukan penuntutuan maupun penjatuhan putusan, demikian pula dengan jaksa dan hakim. Jadi dari segi ruang lingkup tugas yang dijalankan, advokat memiliki jangkauan yang lebih luas, akan tetapi dari segi power atau kekuatan, advokat tidak lebih superior dibandingkan dengan mereka.

Meski tidak memilik power sebesar penegak hukum lain, keberadaan advokat sangat penting bagi masyarakat untuk membela hakhak seseorang (individu) dalam menghadapi

Tentang hal ini baca Satjipto Rahardjo, "Hukum Progresif: Hukum yang Membebaskan". Jurnal Hukum Progresif Vol. 1 No. 1 April 2005, Semarang: PDIH UNDIP dan Yoha-nes Suhardin, "Peranan Hukum dalam Mewujudkan Kese-jahteraan Masyarakat". Jurnal Hukum Pro Justitia Vol. 25 No. 3 Juli 2008, Bandung: FH UNPAR; A. Reni Widyastuti, "Penegakan Hukum: Mengubah Strategi dari Supremasi Hukum ke Mobilisasi Hukum untuk Mewujudkan Kesejahteraan dan Keadilan". Jurnal Hukum Pro Justitia Vol. 26 No. 3 Juli 2008, Bandung: FH UNPAR.

4 Lihat penjelasannya dalam Frans Hendra Winarta, "Kedudukan Advokat atau Penasihat Hukum sebagai Penegak Hukum, Advokat atau Penasihat Hukum Menuju Undang-undang Profesi", Majalah Hukum Pro Justitia Tahun XIV No. 4 Oktober 1996, FH UNPAR Bandung; persoalan hukum. Apabila seseorang individu menghadapi tuntutan pidana dari negara yang mempunyai perangkat polisi, jaksa, hakim, dan lembaga pemasyarakatan, jelas diperlukan advokat untuk membela individu yang berstatus sebagai tersangka atau terdakwa yang sedang menghadapi penyelidikan, penyidikan, penuntutan, dan pemeriksaan di sidang pengadilan. Pembelaan advokat atas tersangka atau terdakwa yang berhadapan dengan negara yang mempunyai perangkat lengkap akan menciptakan keseimbangan dalam proses peradilan sehingga keadilan bagi semua orang (justice for all) dapat tercapai. ${ }^{5}$

Pada banyak kasus, penasihat hukum tidak bisa melakukan tindakan apapun kendati ia mengetahui proses pemeriksaan yang dilakukan terhadap kliennya bertentangan dengan ketentuan prosedural. Misalnya, pertanyaan dari penyidik bersifat menjebak, sugestif, dan tidak memberikan keleluasaan pada orang yang disidik untuk memberikan jawaban. Apabila dalam kasus yang diduga sebagai delik keamanan negara, pendampingan penasihat hukum dalam proses penyidikan tidak banyak gunanya, karena penasihat hukum hanya bisa melihat tanpa bisa mendengar proses tanya jawab dalam penyidikan. Penasihat hukum perlu mendapat hak untuk bisa memberikan pendapat atau nasihat secara langsung kepada tersangka tentang adanya pelanggaran hak-hak kliennya atas prosedur penyidikan yang dilakukan oleh aparat penyidik ataupun penuntut umum. Apabila ada pejabat yang lalai, terhadap pejabat itu harus dikenakan sanksi dan berita acara yang dihasilkan dari proses penyidikan atau pemeriksaan itu harus dinyatakan batal demi hukum. ${ }^{6}$

Frans Hendra Winarta, 2009, Pro Bono Publico, Hak Konstitusional Fakir Miskin untuk Memperoleh Bantuan Hukum, Jakarta: Gramedia Pustaka Utama, hlm 2.

6 Mien Rukmini, 2003, Perlindungan HAM Melalui Asas Praduga Tidak Bersalah dan Asas Persamaan Kedudukan dalam Hukum pada Sistem Peradilan Pidana Indonesia, Bandung: Alumni, hlm. 147-148. Bandingkan dengan tulisan Yoserwan. "Model Sinkronisasi dan Koordinasi Pelaksanaan Tugas Aparat Penegak Hukum dalam Mewujudkan Sistem Peradilan Pidana Terpadu (Integrated Criminal Justice System)". Jurnal Hukum Respublica Vol. 7 No. 1 November 2007. Pekanbaru: FH Univ. Lancang Kuning 
Sebagaimana sebuah profesi, keberhasilan atau kegagalan pencapaian tujuan merupakan salah satu ukuran untuk menentukan apakah seorang advokat atau organisasi advokat dapat dinilai kinerjanya sebagai baik atau buruk. Memang untuk menentukan hal ini tidaklah mudah, karena pada umumnya, seorang advokat adalah seorang professional yang dapat melakukan pekerjaan tanpa harus bernaung di bawah sebuah organisasi keprofesian ataupun semacam law office atau law firm. Kebebasan ini menyebabkan untuk mengukur kinerja berdasarkan ukuran-ukuran atau indikator keberhasilan kinerja tidak bisa secara eksak diukur dengan menggunakan ilmu yang terkait, yaitu manajemen. Akan tetapi dengan memperhatikan perkembangan manajemen modern yang mengharuskan untuk selalu menyeimbangkan antara rencana, pelaksanaan, hasil, dampak, dan pengawasan menyebabkan seorang advokat yang professional itupun harus menyesuaikan diri.

Jika sudah ada ukuran keberhasilan atau kegagalan melalui penilaian indikator kinerja, maka pengawasan kinerja pun bisa menjadi lebih mudah. Seorang pengawas atau penilai tinggal mencocokkan antara apa yang telah direncanakan atau diprogramkan dengan capaian yang telah diperolehnya. Permasalahannya adalah bidang pekerjaan advokat tidak selalu direncanakan terlebih dahulu. Meski advokat mencari uang dengan membantu orang lain menyelesaikan masalah, sesungguhnya advokat tidak ingin orang lain mempunyai masalah yang menimbulkan kesulitan dalam kehidupannya. Tidak semua advokat menganggap musibah orang lain merupakan rejeki baginya, atau dengan kata lain seorang advokat tidak akan merencanakan musibah orang lain sebagai bagian dari rencana kerja.

Advokat dalam melaksanakan pekerjaan, tidak hanya terkait dengan bidang keahlian sebagai penegak hukum (hardskill), akan tetapi terikat dengan kode etik sebagai softskillnya. Bidang yang satu ini merupakan bagian dalam (internal) dari profesi advokat yang penegak profesinya dilakukan oleh organisasi profesi. Dengan kata lain, pengawasan terhadap advokat dalam kinerjanya, bukan hanya berkaitan dengan hardskill dalam pendampingan terhadap klien, akan tetapi juga bagaimana proses pendampingan itu yang lebih banyak terkait dengan etika profesinya. ${ }^{7}$ Artikel ini bermaksud untuk membahas mengenai penilaian kinerja berdasarkan indikator kinerja yang dikenal dalam ilmu ekonomi dan pengawasan kinerja advokat dalam penanganan perkara pidana baik dari sisi hardskill maupun softskill.

\section{Permasalahan}

Permasalahan mengenai advokat yang ditimbulkan dari munculnya undang-undang advokat dan yang terkait dengan kinerja advokat relatif cukup banyak untuk digali. Akan tetapi dalam artikel ini, ada dua permasalahan yang dibahas pada artikel ini. Pertama, mengenai penilaian terhadap kinerja advokat dalam pemberian bantuan dan pelayanan jasa hukum; dan kedua adalah mengenai pengawasan terhadap kinerja advokat dalam pemberian bantuan dan pelayanan jasa hukum di Jawa Tengah dan DI Yogyakarta.

\section{Metode Penelitian}

Untuk memecahkan permasalahan tersebut, penelitian ini didesain dengan menggunakan metode survey, observasi, wawancara dan studi pustaka. Penelitian ini merupakan penelitian empiris dengan menggunakan pendekatan sosiologis dan ilmu ekonomi. Sumber data utama dalam penelitian ini adalah kata-kata dan tindakan, selebihnya adalah data tambahan seperti dokumen dan lain-lain. Lokasi penelitian di Jawa Tengah dan DI Yogyakarta. Sasaran penelitian ini adalah norma hukum, dan perilaku masyarakat. Informan penelitian ditentukan secara purposive yang meliputi advokat, baik yang berpraktik mandiri, berada di bawah naungan law firm, law office, maupun lembaga bantuan hukum; aparat hukum, dan pengguna jasa advokat. Informan penelitian tidak bersifat

Lihat mengenai diskursus etika dalam profesi hukum pada Suadarma Ananda, "Hukum dan Moralitas". Jurnal Hukum Pro Justitia Vol. 26 No. 3 Juli 2008; Andre Ata Ujan, "Profesi: Sebuah Tinjauan Etis". Studia Philosophica et Theologica, Vol. 7 No. 2 Oktober 2007; Frans Hendra Winata, "Pencapaian Supremasi Hukum yang Beretika dan Bermoral”, Jurnal Hukum Pro Justitia Tahun XX No. 1 Januari 2003, Bandung: FH UNPAR. 
limitatif karena menggunakan prinsip bola salju (snowball principle). Data dikumpulkan dengan metode interaktif dan non interaktif. Data yang diperoleh dianalisis dengan model analisis interaktif.

\section{Pembahasan}

Pengertian Kinerja dan Indikator Pengukurannya

Kinerja adalah sesuatu yang dicapai, prestasi yang diperlihatkan, dan kemampuan kerja (tentang peralatan). Kinerja meliputi kinerja pegawai, kinerja unit, dan kinerja lembaga itu sendiri. Kinerja merupakan suatu hasil kerja yang dapat dicapai oleh seseorang atau kelompok dalam suatu organisasi, sesuai dengan wewenang dan tanggung jawab masingmasing, dalam rangka mencapai tujuan organisasi yang bersangkutan secara legal, tidak melanggar hukum dan sesuai dengan moral dan etika. ${ }^{8}$

Masalah pengukuran kinerja, baik organisasi publik maupun swasta terkait erat dengan akuntabilitas dan kinerja dari institusi yang bersangkutan. Kaplan dan Norton menyajikan suatu kerangka yang holistik dan komprehensif dalam menterjemahkan tujuan strategis organisasi ke dalam pengukuran kinerja menyeluruh yang mencakup empat perspektif, yaitu financial performance; customer satisfaction; internal business process; and learning and growth. ${ }^{9}$ Berikut penjelasan dari masing-masing perspektif tersebut.

Berdasarkan perspektif finansial, menurut Kaplan pada saat perusahaan melakukan pengukuran secara finansial, maka hal pertama yang harus dilakukan adalah mendeteksi keberadaan industri yang dimilikinya. Kaplan menggolongkan tiga tahap perkembangan industri yaitu; growth, sustain, dan harvest. Dari tahap-tahap perkembangan industri tersebut akan diperlukan strategi-strategi yang berbeda-beda. Dalam

8 Suyadi Prawirosentono, 1997, Kebijakan Kinerja Karyawan (Manajemen Sumber Daya Manusia), Yogyakarta: Penerbit BPFE, hlm. 82

9 Robert S. Kaplan \& David P. Norton. 1996. Translating Strategy Into Action The Balanced Scorecard. BostonMassachusetts: Harvard Business School Press, hlm. 2122 perspektif finansial, terdapat tiga aspek dari strategi yang dilakukan suatu perusahaan, yaitu; pertumbuhan pendapatan dan kombinasi pendapatan yang dimiliki suatu organisasi bisnis; penurunan biaya dan peningkatan produktivitas; dan penggunaan aset yang optimal dan strategi investasi. ${ }^{10}$

Perspektif customer dalam Balanced Scorecard mengidentifikasi bagaimana kondisi customer mereka dan segmen pasar yang telah dipilih oleh perusahaan untuk bersaing dengan kompetitor mereka. Segmen yang telah mereka pilih ini mencerminkan keberadaan customer tersebut sebagai sumber pendapatan mereka. Dalam perspektif ini, pengukuran dilakukan dengan lima aspek utama. ${ }^{11}$ Pertama, pengukuran pangsa pasar. Pengukuran terhadap besarnya pangsa pasar perusahaan mencerminkan proporsi bisnis dalam satu area bisnis tertentu yang diungkapkan dalam bentuk uang, jumlah customer, atau unit volume yang terjual atas setiap unit produk yang terjual. Kedua, customer retention, Pengukuran dapat dilakukan dengan mengetahui besarnya prosentase partumbuhan bisnis dengan jumlah customer yang saat ini dimiliki oleh perusahaan.

Ketiga, customer acquisition. Pengukuran dapat dilakukan melalui prosentase jumlah penambahan customer baru dan perbandingan total penjualan dengan jumlah customer baru yang ada. Keempat, customer satisfaction. Pengukuran terhadap tingkat kepuasan pelanggan ini dapat dilakukan dengan berbagai macam teknik diantaranya adalah: survei melalui surat (pos), interview melalui telepon, atau personal interview. Kelima, customer profitability. Pengukuran terhadap customer profitability dapat dilakukan dengan menggunakan teknik Activity Based-Costing ( $\mathrm{ABC}$ ).

Oleh karena aspek tersebut masih bersifat terbatas, maka perlu dilakukan pengukuranpengukuran yang lain yaitu pengukuran terhadap semua aktivitas yang mencerminkan nilai tambah bagi customer yang berada pada pangsa pasar perusahaan. Pengukuran tersebut dapat berupa: atribut produk atau jasa yang dibe-

10 Ibid

11 Ibid, hlm. 67 
rikan kepada customer (seperti: kegunaan, kualitas dan harga), hubungan atau kedekatan antar customer (seperti: pengalaman membeli dan hubungan personal), image dan reputasi produk atau jasa di mata customer.

Perusahaan berdasarkan perspektif proses bisnis internal, melakukan pengukuran terhadap semua aktivitas yang dilakukan oleh perusahaan baik manajer maupun karyawan untuk menciptakan suatu produk yang dapat memberikan kepuasan tertentu bagi customer dan juga para pemegang saham. Dalam hal ini perusahaan berfokus pada tiga proses bisnis utama yaitu: proses inovasi, proses operasi, proses pasca penjualan.

Proses inovasi merupakan salah satu kritikal proses dalam proses penciptaan nilai tambah bagi customer, dimana efisiensi dan efektivitas serta ketepatan waktu dari proses inovasi ini akan mendorong terjadinya efisiensi biaya pada proses penciptaan nilai tambah bagi customer. Secara garis besar proses inovasi dapat dibagi menjadi dua yaitu: pengukuran terhadap proses inovasi yang bersifat penelitian dasar dan terapan; dan pengukuran terhadap proses pengembangan produk.

Proses operasi dilakukan oleh masingmasing organisasi bisnis, lebih menitikberatkan pada efisiensi proses, konsistensi dan ketepatan waktu dari barang dan jasa yang diberikan kepada customer. Pada proses operasi, pengukuran terhadap kinerja dilakukan terhadap tiga dimensi. Pertama, pengukuran terhadap efisiensi waktu yang diperlukan (time measurements). Pengukuran ini diperlukan untuk menghasilkan produk (waktu proses produksi) sangat berkaitan erat dengan keseluruhan waktu yang diperlukan untuk menghasilkan produk sampai produk siap untuk dijual.

Berdasarkan hal tersebut, pengukuran waktu proses awal (cycle time) dapat dilakukan sejak diterimanya order pelanggan, order pelanggan tersebut (produksi dalam batch) dijadwalkan untuk diproduksi, dibuatnya order permintaan bahan baku untuk keperluan proses produksi, bahan baku tersebut diterima, dan ketika produksi direncanakan. Akhir proses (end cycle time) dideteksi dari produksi dalam unit atau batch telah diselesaikan, order (barang jadi) siap untuk dikirim dan disimpan dalam persediaan barang jadi, order dikirimkan kepada customer, order diterima oleh customer.

Kedua, pengukuran terhadap kualitas proses produksi (quality process measurements) Dalam hal kualitas proses produksi, perusahaan diharapkan dapat melakukan berbagai macam pengukuran terhadap proses produksi yang dideteksi dari adanya hal-hal sebagai berikut tingkat kerusakan produk dari proses produksi, perbandingan produk bagus yang dihasilkan dengan produk bagus yang masuk dalam proses, bahan buangan (waste), bahan sisa (scrap), besarnya angka pengerjaan kembali (rework), besarnya tingkat pengembalian barang dari customer, kesesuaian prosentase kualitas proses dengan statistical process control.

Ketiga, pengukuran terhadap efisiensi biaya proses produksi (process cost measurements). Dimensi ketiga dari pengukuran terhadap proses operasi adalah pengukuran sejumlah biaya yang telah dikeluarkan untuk menghasilkan produk. Pada sistem pembebanan biaya tradisional, sistem akuntansi telah banyak melakukan pengukuran atas biaya yang dikeluarkan atas penggunaan sumber-sumber dalam departemen, dalam proses operasi ataupun kewajiban individu. Tetapi sistem ini tidak banyak memberikan kontribusi dalam mengkalkulasi biaya aktivitas yang muncul dalam rangka menghasilkan produk (proses operasi), sehingga dikembangkan sistem Activity Based Costing dan sistem ini mampu membantu manajer dalam meakukan akumulasi terhadap keseluruhan biaya yang tejadi pada proses operasi. Sistem $A B C$ ini (bersama-sama dengan pengukuran kualitas dan waktu proses produksi) akan menghasilkan tiga parameter penting untuk mengkarakteristikkan pengukuran proses bisnis internal.

Keempat, pelayanan purna jual. Pengukuran ini menjadi bagian yang cukup penting dalam proses bisnis internal, karena pelayanan purna jual ini akan berpengaruh terhadap tingkat kepuasan pelanggan. Termasuk dalam aktivitas purna jual diantaranya adalah: garansi dan aktivitas reparasi, perlakuan terhadap produk cacat atau rusak, proses pembayaran yang 
dilakukan oleh customer pada transaksi penjualan yang dilakukan secara kredit.

Perspektif yang terakhir dalam Balanced Scorecard adalah perspektif pertumbuhan dan pembelajaran. Kaplan mengungkapkan betapa pentingnya suatu organisasi bisnis untuk terus memperhatikan karyawannya, memantau kesejahteraan karyawan dan meningkatkan pengetahuan karyawan karena dengan meningkatnya tingkat pengetahuan karyawan akan meningkatkan pula kemampuan karyawan untuk berpartisipasi dalam pencapaian hasil ketiga perspektif di atas dan tujuan perusahaan. Dalam perspektif ini, terdapat tiga dimensi penting yang harus diperhatikan untuk melakukan pengukuran yaitu; kemampuan karyawan, kemampuan sistem informasi, adanya motivasi, pemberian wewenang dan pembatasan wewenang kepada karyawan, sedangkan pengukuran terhadap kinerja tim dapat dilakukan dengan beberapa indikator seperti yang telah dikembangkan oleh perusahaan Nasional adalah: survey internal terhadap tim, level pembagian keuntungan atas proyek bersama, jumlah penugasan, prosentase kebijakan baru perusahaan tertulis, prosentase perencanaan bisnis yang dikembangkan oleh tim, jumlah anggota tim yang mendapat bagian dalam pembagian keuntungan atau laba. ${ }^{12}$

Kelemahan dalam Pengukuran Kinerja Advokat dan Organisasi Bantuan Hukum

Pengukuran kinerja seorang advokat tak dapat dinilai secara instan dari hasil akhir yang berupa menang atau kalah, akan tetapi dari bagaimana dia memberi pelayanan yang baik dan kelancaran penanganan perkara di dalam mau pun di luar pengadilan. Banyak advokat yang mengemukakan bahwa menang kalah bukan ukuran keberhasilan menangani suatu perkara, akan tetapi kesungguhan dan keteguhan hati dalam memberikan jasa atau bantuan hukum kepada klien itulah yang menjadi ukurannya. ${ }^{13}$ Akan tetapi tak dapat dipungkiri bahwa tak se-

12 Ibid, hlm. 142

13 Lihat tentang tata cara pemberian bantuan hukum ini pada Tata Wijayanta, "Bantuan Hukum Golongan Tidak Mampu dalam Perkara Perdata di Pengadilan Negeri Yogyakarta", Jurnal Mimbar Hukum Vol. 24 No. 1 Februari 2012, Yogyakarta: FH UGM. orangpun yang berurusan dengan hukum dan menggunakan jasa advokat ingin agar perkara yang dihadapi itu ingin kalah. Keinginan klien dengan menggunakan advokat adalah untuk menang, dalam arti bebas atau ringannya hukuman dalam perkara pidana atau mendapat ganti rugi yang layak bagi penggugat atau sebaliknya bagi tergugat dalam perkara perdata.

Meski pendapat menang kalah dalam ilmu manajemen - terutama yang berkaitan dengan pengukuran kinerja - tidak benar, akan tetapi pendapat tersebut surat menjadi hal yang lumrah dalam dunia hukum. Seorang klien membayar mahal advokat bukan untuk kalah, mereka menginginkan kemenangan. Inilah yang terkadang mendorong advokat untuk melakukan halhal yang sebenarnya melanggar etika profesinya demi memenuhi keinginan klien. Apalagi jika sumber dana dari klien tak terbatas, maka advokat akan semakin bersemangat untuk memenangkan suatu perkara yang ditanganinya. Kecenderungan ini menyebabkan timbulnya malpraktik dalam dunia peradilan khususnya advokat, yang berujung pada timbulnya mafia peradilan, karena kesuksesan atau kegagalan dalam menangani suatu perkara merupakan suatu jalinan kerjasama yang rumit dalam jaringan peradilan yang akhirnya disebut sebagai mafia peradilan.

Kinerja advokat secara sederhana dapat didefinisikan sebagai efektivitas jasa yang disediakan oleh advokat dan efisiensi sumberdaya yang dialokasikan dan digunakan untuk menyiapkan jasa tersebut. Adapun indikator kinerja adalah pernyataan numerik, simbol atau verbal yang diperoleh dari statistik dan data pemberian jasa yang digunakan untuk memberi ciri terhadap kinerja seorang advokat. Jadi, indikator kinerja berfungsi sebagai alat untuk menilai kualitas dan efektivitas jasa dan kegiatan lain yang disediakan oleh advokat, dan untuk menilai efisiensi sumber daya yang dialokasikan untuk keperluan jasa dan kegiatan tersebut. Sebagai sebuah alat perencanaan dan evaluasi, indikator kinerja mempunyai beberapa sasaran utama yaitu: menyediakan kontrol dalam proses manajemen; sebagai dasar referensi dan bahan dialog antara para advokat perpustaka- 
an, lembaga/kantor induk, dan masyarakat pemakai; dan menyiapkan analisis komparatif terhadap kinerja advokat dan jasa informasi yang mempunyai misi atau sasaran yang identik.

Sesuai dengan aspek-aspek pengukuran kinerja, indikator kinerja dapat digolongkan menjadi beberapa jenis, yaitu: indikator efisiensi, indikator efektivitas, indikator efektivitas biaya dan indikator dampak. Indikator efisiensi menunjukkan hubungan antara jasa hukum yang disediakan (output) dan sumber daya yang dibutuhkan untuk membuatnya (input). Indikator efektivitas menunjukkan hubungan antara jasa yang disediakan oleh advokat (output) dengan penggunaannya. Melalui indikator ini akan diketahui berapa banyak orang yang telah menggunakan jasa dan seberapa puas mereka terhadap jasa tersebut. Indikator efektivitas-biaya menunjukkan hubungan antara penggunaan jasa dengan sumber daya yang dibutuhkan untuk membuatnya (input). Dengan indikator ini dapat diketahui seberapa besar harga untuk setiap pemakai, atau setiap pemakaian, dan kapan investasi akan kembali. Indikator dampak menunjukkan hubungan antara efektivitas jasa dengan penyebaran atau meluasnya jasa. Melalui indikator ini akan dapat diketahui proporsi pemakai yang nyata-nyata menggunakan jasa, seringnya mereka menggunakannya, dan seringnya mereka menemukan apa yang dibutuhkan dengan tepat.

Berdasarkan pada penjelasan teoretis tersebut di atas, hampir semua advokat, kantor advokat/law office maupun lembaga bantuan hukum yang diteliti, belum seluruhnya menerapkan atau menjalankan proses manajemen yang berorientasi pada mutu atau kualitas sebagai suatu hasil akhir dari produk atau pelayanan. Orientasi yang menitikberatkan pada menang atau kalah dalam penanganan perkara menyebabkan prinsip manajemen diabaikan begitu saja. Transparansi sebagai salah satu prasyarat dalam pengukuran kinerja juga sulit diperoleh.

Tampaknya kesadaran para advokat untuk mengukur kinerjanya sendiri belum ada, sehingga cara kerja yang dilakukan tak dapat diukur secara statistik. Memang bidang pekerjaan keadvokatan memiliki ciri khas tersendiri yang tentu saja tak dapat diukur secara eksak, akan tetapi meski demikian bukan berarti tak bisa diukur. Advokat belum terbiasa untuk melakukan evaluasi terhadap kinerja sebagai suatu keseluruhan, bukan hanya pada perkara yang dibela atau substansi perkara itu, padahal yang berkaitan dengan kinerja bukan hanya itu. Kesadaran untuk mengukur kinerja perlu ditumbuhkan, karena hal ini diperlukan untuk langkah perencanaan program kerja di masa mendatang.

Advokat yang berpraktik mandiri ataupun kantor hukum dan lembaga bantuan hukum berdasarkan hasil penelitian, tampak tidak familiar dengan prinsip indikator pengukuran kinerja sebagaimana dijelaskan di atas, sehingga untuk mengukur kinerja mereka sangat susah. Oleh karena itu, nampaknya mereka perlu segera mengadopsi pengukuran kinerja ini agar kinerja mereka bisa diukur agar penyusunan program kerja pada tahun berikutnya dapat terencana dengan baik. Oleh karena tidak ada indikator dalam bidang hukum yang bisa digunakan untuk menilai kinerja advokat, maka di bawah ini akan diuraikan mengenai cara kerja (istilah ini sebenarnya lebih tepat jika dibandingkan dengan kinerja) advokat dalam menangangi perkara pidana. Tentu saja cara kerja ini hanya terbatas pada perkara yang ditangani tanpa melibatkan atau menggunakan indikator kinerja yang ada pada ilmu ekonomi.

Untuk mengukur keberhasilan atau kegagalan kinerja advokat, dapat dilihat dari berbagai sudut pandang terutama yang menjadi fokus kajian di sini adalah cara kerjanya. Bagi advokat yang tergabung dalam suatu organisasi bantuan hukum atau organisasi professional yang bersifat komersial (benefit oriented) nampaknya tidak terlalu susah, karena mereka sudah punya standar tersendiri dalam melayani klien termasuk evaluasi atas hasil pekerjaan dan pengawasannya. Akan tetapi terhadap advokat yang bekerja secara mandiri atau kantor hukum yang tidak memiliki manajemen penanganan perkara yang baik, akan sangat sulit mengukur kinerja mereka karena segala sesuatunya dilakukan secara pribadi. 
Berdasarkan penelitian yang dilakukan terhadap advokat, baik yang berpraktik mandiri, pada kantor hukum yang semi professional (tidak ada manajemen, penggunaan istilah kantor hukum sebatas sekretariat saja) maupun professional (menggunakan manajemen modern), dan organisasi bantuan hukum di Yogyakarta, Solo, Semarang, Pekalongan, Banyumas, dan Jakarta diperoleh data sebagai berikut. Para klien datang ke advokat atau kantor advokat atau organisasi bantuan hukum berdasarkan informasi dari seseorang atau media atau aparat penegak hukum. Kedatangan pertama seorang klien dimanfaatkan oleh advokat untuk menggali data melalui pengungkapan perkara berdasar alur cerita yang dibuat oleh klien. Bagi advokat yang berpraktik mandiri atau kantor hukum yang semi professional, setelah mendengar cerita klien lalu disodori dengan surat kuasa dengan beberapa ketentuan yang disepakati bersama. Sebelum penandatangan surat kuasa, disepakati terlebih dahulu besaran biaya yang harus dibayar klien dan cara pembayarannya. Hal seperti ini sebenarnya kelemahan dari seorang advokat yang selalu terburu-buru dalam melakukan penandatangan surat kuasa tanpa terlebih dahulu menggali secara mendalam cerita dari klien.

Bagi advokat yang berpraktik pada kantor hukum professional maupun organisasi bantuan hukum, sebelum mereka memberi kesanggupan untuk memberi jasa atau bantuan hukum, akan mereview terlebih dahulu atas cerita yang diberikan oleh klien itu. Bahkan mereka melakukan investigasi untuk memeriksa kebenaran cerita klien. Tentu saja hal ini dilakukan oleh mereka yang mempunyai divisi investigasi. Apabila hasil investigasi menunjukkan apa yang dikatakan oleh klien itu benar, maka akan diputuskan untuk menerima atau menolak memberi jasa atau bantuan hukum pada klien. Jadi keputusan untuk itu dilakukan secara kolektif melalui rapat atau diputuskan oleh pimpinan kantor hukum.

Apabila diputuskan untuk memberi jasa atau bantuan hukum, maka akan dibentuk sebuah tim, yang diikuti dengan penandatanganan surat kuasa. Bagi yang mampu akan dibi- carakan lebih lanjut mengenai biaya pemberian jasa hukum, dan bagi yang tidak mampu akan diberikan bantuan hukum secara cuma-cuma. Jalannya perkara akan selalu dipantau oleh kantor hukum atau organisasi bantuan hukum, terutama dalam kelancaran beracara yang berkaitan dengan argumentasi dalam dokumen beracara maupun pembuktian. Tim yang ditunjuk juga memiliki kewajiban untuk melaporkan setiap kejadian yang berkaitan dengan pemberian jasa atau bantuan hukum selama jalannya perkara.

Jika dirunut secara kronologis, seseorang yang membutuhkan jasa hukum atau bantuan hukum seorang advokat dapat dimulai pada waktu ataupun sebelum proses penyidikan yang dilakukan oleh polisi. Kecenderungan yang ada adalah kebutuhan untuk menggunakan jasa advokat timbul setelah seseorang ditetapkan sebagai tersangka oleh penyidik. Tentu saja hal ini terkait dengan hak yang dipunyai oleh seorang tersangka, juga keinginan untuk memperoleh perlindungan dan rasa aman pada saat penyidikan.

Ketentuan hukum yang berkaitan dengan kedudukan advokat dalam proses penyidikan hanyalah dijelaskan dalam Pasal 50 - Pasal 74 KUHAP. Ketentuan tersebut memberikan hak kepada tersangka untuk diperlakukan sama dalam proses penegakan hukum. Hal ini sesuai dengan prinsip equality before the law, bahwa setiap orang memiliki kedudukan yang sama di depan hukum dan pemerintahan. Pasal 50 Pasal 74 KUHAP akan terselenggara dengan baik bilamana dibantu oleh advokat selaku penasihat hukum. Untuk itu kedudukan seorang advokat adalah salah satu pilar dari sisi hak-hak tersangka dalam rangka proses law enforcement. Seorang advokat harus benar-benar melakukan pembelaan sesuai dengan hak-hak tersangka sebagaimana diatur dalam undang-undang. Sebab di sisi lain tersangka akan diserang semaksimal mungkin oleh jaksa penuntut umum guna dijerat sebagai pelaku tindak pidana berdasarkan hasil pemeriksaan/BAP penyidik. ${ }^{14}$

14 Achmad Rifai, "Kedudukan dan Peran Advokat dalam Proses Penyelesaian Perkara Pidana". Jurnal Al-Ihkam, Vol. III No. 2 Desember 2008, hlm. 317 
Meski kedudukan advokat dalam proses penyidikan bersifat pasif, artinya ia hanya berhak mendampingi dan tidak ada hak untuk mengajukan keberatan terhadap pertanyaan-pertanyaan penyidik, akan tetapi keberadaan mereka tetap positif, terutama untuk mencegah terjadinya kekerasan pada tersangka. Dari berbagai penelitian, kekerasan terhadap tersangka kerap terjadi ketika advokat atau penasehat hukum tak mendampingi klien atau tersangka dalam proses penyidikan. Hal yang patut dipertimbangkan adalah hak bicara pada penasehat hukum dalam penyidikan tidak seharusnya dilarang. Menjadi kewajiban dari advokat apabila dalam penyidikan dijumpai kekerasan terhadap tersangka untuk mengungkap, melaporkan, dan menyelesaikan perilaku penyidik yang melanggar hukum dan hak asasi tersangka.

Peran advokat - sebagai penegak hukum, sama dengan penegak hukum lainnya - dalam persidangan untuk mendampingi klien adalah untuk menemukan kebenaran materiil, sehingga tidak pada tempatnya bagi advokat untuk menyembunyikan kebenaran yang untuk kepentingan klien. Akan tetapi, yang terjadi dalam dunia kenyataan adalah sebaliknya, kebenaran yang tidak menguntungkan bagi klien, ditutupi agar kliennya tidak mendapatkan hukuman yang berat atau malah jika bisa dibebaskan. Pada satu sisi ini merupakan strategi advokat untuk memenangkan perkara, akan tetapi pada sisi lain hal ini merupakan sikap yang paradoks dengan tugas dan kewajiban sebagai penegak hukum.

Menjadi tugas dan kewajiban pula bagi advokat untuk membongkar kebusukan-kebusukan yang ada dalam penegakan hukum. Apabila dalam proses penyidikan terjadi kekerasan, dan karena sifat pendampingan advokat yang pasif dalam proses itu, maka selain mengungkap melalui prosedur yang ada, tempat lain yang tepat untuk itu adalah pada saat persidangan berlangsung. Sering dijumpai tersangka mencabut keterangan yang diberikan kepada penyidik karena perolehan keterangan itu dilakukan dengan menggunakan kekerasan, sesuatu hal yang dilarang oleh hukum acara sekaligus pelanggaran terhadap hak tersangka untuk diperiksa dengan cara yang bebas dari tekanan. Kendala yang dihadapi adalah hampir semua perkara di mana tersangka keberatan terhadap BAP yang dibuat oleh penyidik dan dijadikan dasar oleh jaksa untuk membuat dakwaan, tidak diterima oleh hakim sebagai alasan untuk meringankan ataupun membebaskan terdakwa. Inilah sebenarnya tugas advokat yang seharusnya dilakukan untuk membongkar kebusukankebusukan dalam penegakan hukum yang dilakukan oleh penegak hukum lainnya.

Dapat juga terjadi, advokatlah yang justru membuat kebusukan-kebusukan dalam penegakan hukum terjadi. Cara kerja seperti ini terjadi karena pergeseran paradigma dari officium nobile ke komersialisasi, dari tugas mulia ke arah kemenangan semata. Dapat dijumpai dari pemberitaan media massa mengenai cara kerja dan perilaku negatif advokat, padahal advokat sudah dibekali dengan rambu-rambu kode etik dan perundang-undangan yang ada dalam pelaksanaan tugas dan kewajibannya. Inilah yang dikatakan oleh Amir sebagai mewaspadai perangkap tikus. ${ }^{15}$

Dikatakan oleh Amir $^{16}$ bahwa banyak sekali contoh empirik perilaku korup yang dilakukan oleh sejumlah oknum penyedia jasa hukum yang patut dihindari. Ada beberapa rambu yang bisa menjadi "perangkap tikus" bagi para professional di bidang jasa hukum yang melakukan pelanggaran. Beberapa di antaranya yang paling penting untuk dijadikan pedoman oleh advokat adalah sebagai berikut. Pertama, upaya advokat menyuap polisi, jaksa dan hakim dengan tujuan untuk menghindari proses penyelidikan, meringankan tuntutan, dan atau mempengaruhi putusan pengadilan atas kliennya, merupakan kasus yang paling menonjol dalam wacana penegakan hukum dewasa ini. Padahal, dengan diberlakukannya pembaharuan undangundang pemberantasan korupsi, perbuatan ini tergolong korupsi, sebagaimana diatur pada Pasal 6 ayat (1) UU No. 20 Tahun 2001 tentang Pemberantasan Tindak Pidana Korupsi. Pasal ini menentukan bahwa memberi atau menjanjikan

\footnotetext{
15 Ari Yusuf Amir, 2008, Strategi Bisnis Jasa Advokat, Yogyakarta: Navila Idea, hlm. 157

16 Ibid, hlm. 158-161
} 
sesuatu kepada hakim dengan maksud untuk mempengaruhi putusan perkara yang diserahkan kepadanya untuk diadili. Ancaman pidana yang diberikan cukup berat, yaitu 3 (tiga) sampai 5 (lima) tahun penjara dan denda antara Rp. 150.000.000,- sampai Rp. 750.000.000,-

Kedua, godaan untuk menerima suap dari pihak-pihak tertentu juga kerap dialami para advokat dalam mewakili kepentingan klienya, terutama dalam proses litigasi. Pada proses peradilan ini, tidak hanya advokat yang rentan pada godaan suap, tetapi begitu pun hakim sebagai pengambil keputusan. Itulah sebabnya, telah ada rambu-rambu berupa Pasal 6 ayat (2) UU No. 20 Tahun 2001, yang menentukan bahwa bagi hakim yang menerima pemberian atau janji sebagaimana dimaksud dalam ayat (1) huruf a atau advokat yang menerima pemberian atau janji sebagaimana dimaksud pada ayat (1) huruf $a$, dipidana dengan pidana yang sama sebagaimana dimaksud dalam ayat (1).

Ketiga, secara spesifik, seorang advokat yang menerima suap saat mewakili klien pada proses persidangan di pengadilan, juga dapat dijerat sebagai pelaku korupsi menurut Pasal 12 huruf d UU No. 20 Tahun 2001 jo UU No. 31 Tahun 1999, yang menentukan bahwa seseorang yang menurut ketentuan peraturan perundangundangan ditentukan menjadi advokat untuk menghadiri sidang pengadilan menerima hadiah atau janji, padahal diketahui atau patut diduga bahwa hadiah atau janji tersebut untuk mempengaruhi nasihat atau pendapat yang akan diberikan, berhubung dengan perkara yang diserahkan kepada pengadilan untuk diadili.

Keempat, tentu saja, para penyuap advokat juga dapat dijerat dengan "perangkap tikus" ini apabila perbuatannya dimaksudkan agar mempengaruhi nasihat atau pendapat advokat, yang nantinya akan berhubungan dengan perkara yang diserahkan kepada pengadilan untuk diadili. Rumusan Pasal 6 ayat (1) huruf $b$ UU No. 31 Tahun 1999 jo UU No. 20 Tahun 2001 menentukan bahwa memberi atau menjanjikan sesuatu kepada seseorang yang menurut ketentuan peraturan perundang-undangan ditentukan menjadi advokat untuk menghadiri sidang pengadilan dengan maksud untuk mempenga- ruhi nasihat atau pendapat yang akan diberikan berhubungan dengan perkara yang diserahkan kepada pengadilan untuk diadili.

Selain "perangkap tikus" sebagaimana diurai di atas, ada beberapa bentuk perbuatan yang dipatut dihindari oleh seorang advokat dalam menjalankan tugas profesinya. Ketiga bentuk perbuatan tersebut adalah sebagai berikut. ${ }^{17}$ Pertama, berusaha mengabaikan dan menganggap sepele setiap permintaan polisi atau jaksa terhadap klien untuk memenuhi hal-hal sebagaimana yang telah diatur dalam undangundang. Tindakan advokat yang demikian dapat dijerat dengan Pasal 216 ayat (1) KUHP. (Catatan Peneliti: Jika yang maksud adalah perintah polisi atau jaksa yang terkait dengan penanganan perkara, dan perintah itu berdasar pada undang-undang oleh pejabat yang berwenang, maka advokat tidak bisa menolak, akan tetapi apabila yang dimaksud adalah permintaan - bukan perintah - yang tidak berdasar pada undang-undang, atau dengan kata lain permintaan yang dimaksudkan untuk menguntungkan pemberi perintah, maka advokat wajib untuk tidak memenuhinya).

Kedua, membantu klien membuat keterangan palsu dalam proses penyidikan dengan maksud agar klien terlepas dari jeratan pidana. Tindakan ini dapat dijerat dengan Pasal 218 KUHP. Ketiga, membantu klien bersembunyi dari kejaran petugas karena terlibat dalam suatu kejahatan, atau untuk menghindari proses pemeriksaan, penyidikan dan penuntutan. Perbuatan ini dapat dijerat Pasal 221 KUHP.

Berdasarkan penjelasan tersebut dapat terlihat bahwa oleh karena tugas dan kewajiban advokat bersangkut paut dengan nasib seseorang yang dipertaruhkan dalam proses peradilan, selalu saja ada godaan untuk berbuat yang melanggar kewajiban tugas konstitusional maupun etisnya. Berdasarkan hasil penelitian pada beberapa lokasi penelitian, terbukti bahwa perilaku dan cara kerja advokat yang negatif masih bisa dijumpai. Akan tetapi karena kontrol dari komisi pengawas kurang maksimal,

$17 \quad$ Ibid, hlm. 161-162 
perilaku dan cara kerja negatif ini tidak terungkap.

\section{Model Pengawasan Kinerja Advokat dalam Pemberian Bantuan dan Pelayanan Jasa Hu- kum}

Pengawasan, dalam ilmu manajemen merupakan cara untuk mengontrol apakah pekerjaan yang dilakukan atau program yang dijalankan atau pengeluaran (dalam hal keuangan) yang telah dikeluarkan sudah sesuai dengan rencana awal atau tidak. Meskipun telah diungkapkan di atas, banyak advokat yang berpraktik mandiri atau memiliki kantor yang sederhana tidak memiliki program kerja dan perhitungan keuangan sebagaimana layaknya sebuah organisasi atau perusahaan yang bermotif mencari keuntungan sehingga pengawasan terhadap kinerjanya tidak bisa secara rigid menggunakan prinsip indikator kinerja dalam ilmu ekonomi. Banyak kantor hukum, law office maupun organisasi bantuan hukum yang tidak bisa dinilai berdasarkan financial performance, customer satisfaction, internal business process, dan learning and growth. Oleh karena itu untuk mengukur kinerja advokat berikut pengawasannya, perlu diuraikan terlebih dahulu apa sebenarnya tugas dan tujuan dari advokat sebagai profesi.

Profesi advokat dikatakan merupakan suatu profesi yang terhormat (officium nobile), yang berarti di dalamnya terkandung kewajiban mulai dalam pelaksanaan pekerjaan. Ungkapan nobleese obligee berarti kewajiban untuk melakukan hal yang terhormat, murah hati dan bertanggung jawab, hanya dimiliki oleh mereka yang mulia. Tuntuan atas kehormatan profesi advokat ini menyebabkan perilaku seorang advokat haruas jujur dan bermoral tinggi agar memperoleh kepercayaan publik.

Alkotsar mengemukakan bahwa advokat mengemban tugas menegakkan keadilan dan meningkatkan martabat kemanusiaan sehingga pekerjaan advokat dikatakan sebagai officium nobile, pekerjaan yang luhur. Sebagai profesi yang elegan, advokat dituntut untuk dapat bekerja secara professional, terikat pada etika profesi dan tanggung jawab standar keilmuan. Citra advokat sebagai profesi yang anggun akan ditentukan oleh etos profesi dalam arti sejauh mana komunitas advokat sanggup menerapkan standar etika serta keterampilan teknik berprofesi. ${ }^{18}$

Berdasarkan pada penjelasan tersebut, muncul dan beradanya advokat memiliki tujuan yang mulia dalam penegakan hukum. Mengingat posisi advokat yang strategis dalam penegakan hukum yang bergerak dari hulu ke hilir, banyak pula advokat yang kemudian menyalahgunakan kedudukannya, sehingga advokat yang semula merupakan profesi yang officium nobile berubah menjadi saluran yang melahirkan korupsi, meski oleh Rajagukguk dikatakan bahwa sebenarnya dapat juga menjadi individu yang dapat memberantas korupsi. ${ }^{19}$ Berikut bagan mengenai kondisi dan situasi pengawasan kinerja advokat pada saat ini.

Berdasar pada bagan tersebut, sebenarnya kinerja advokat diawasi oleh beberapa pengawas yang dapat dikatakan sebagai pengawasan berlapis. Secara umum, advokat baik secara pribadi maupun kelembagaan diawasi oleh Tuhan, sebagai sumber asal penciptaan manusia, sumber tertinggi dan asal muasal kebenaran dan keadilan. Selain itu, advokat dalam pelaksanaan pekerjaan profesinya, juga diawasi oleh advokat lain, terutama ketika berhadaphadapan. Pada saat inilah sesungguhnya di antara advokat yang berhadapan saling mencari cara dan celah untuk menemukan kesalahankesalahan profesi yang berkaitan dengan perilaku standar etis. Praktik profesi dalam ideologi yang sudah berubah - dari officium nobile ke menang-kalah dalam berperkara - memberi peluang terjadinya pelanggaran etika. Apabila terjadi pelanggaran etika, seorang advokat dapat melaporkan advokat yang melakukan pelanggaran ini ke penegak etika profesi, yaitu Dewan Kehormatan Profesi yang didirikan oleh

18 Artidjo Alkotsar, 2010, Peran dan Tantangan Advokat dalam Era Globalisasi. Yogyakarta: FH Ull Press, hlm. 151.

19 Erman Rajagukguk, "Advokat dan Pemberantasan Korupsi”. Jurnal Hukum, Vol. 15 No. 3 Juli 2008, Yogyakarta: FH UII, hlm. 329. Lihat juga Juscelino F. Colares, "The Evolving Domestic \& International Law Against Foreign Corruption: Some New \& Old Dilemmas Facing the International Lawyer. 5 Washington University Global Studies Law Review, 2006; 
organisasi profesi. Dengan kata lain pengawasan terhadap advokat ini dilandaskan pada inisiatif advokat lain melalui laporan atau pengaduan pada penegak etika profesi.

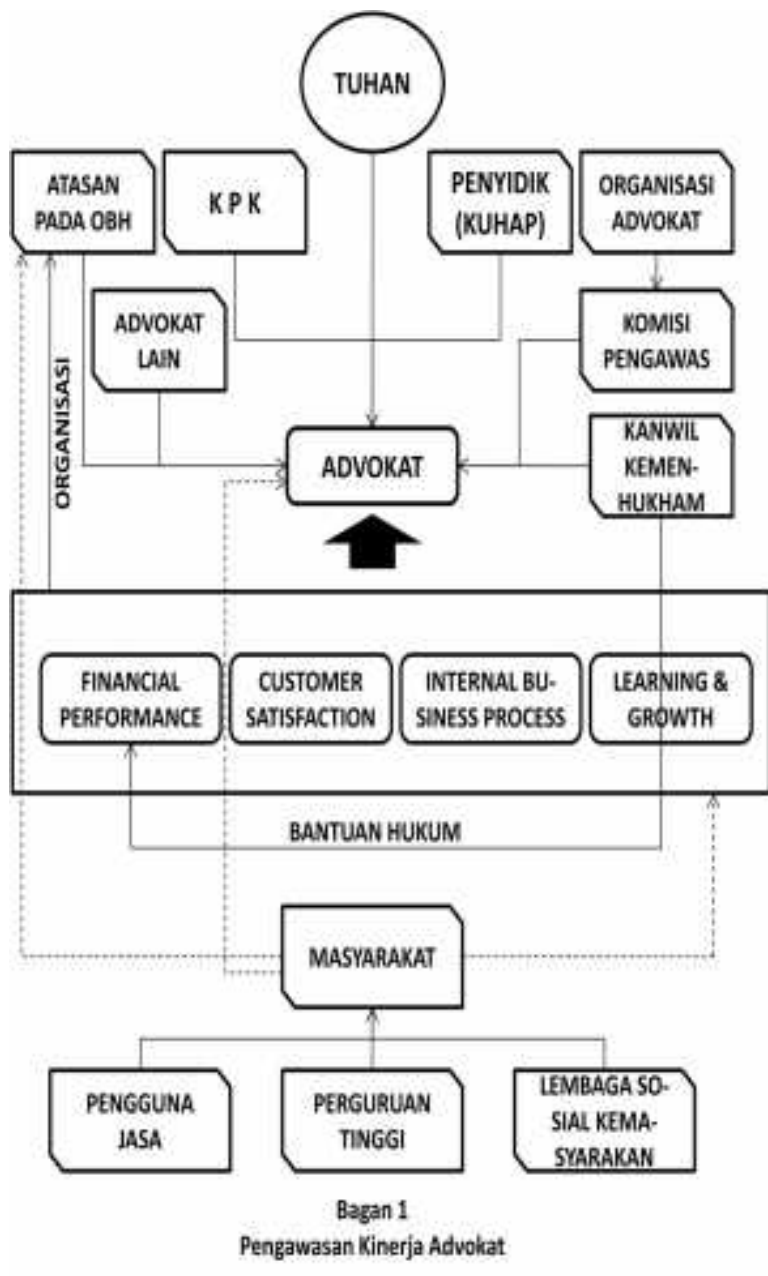

Pada saat ini, advokat berafiliasi atau bergabung dengan organisasi profesi, baik yang parsial (semacam Ikadin, APHI, AAI, dan sebagainya) maupun organisasi yang menaungi organisasi profesi yang parsial itu (baik Peradi mau pun KAl). Advokat yang tergabung dalam organisasi profesi itu, diawasi oleh organisasi profesi melalui komisi pengawas atau Dewan Kehormatan Profesi yang didirikan oleh organisasi profesi tersebut. Dewan Kehormatan Profesi ini melakukan pengawasan terhadap advokat bersifat pasif dan aktif. Pasif apabila Dewan Kehormatan Profesi hanya menerima laporan atau pengaduan dari advokat lain, customer (pelanggan/klien), maupun masyarakat. Aktif apabila Dewan Kehormatan Profesi melakukan penga- wasan langsung terhadap praktik seorang advokat. Dapat dikatakan pengawasan ini adalah pengawasan internal profesi.

Berdasarkan hasil penelitian mengenai pengawasan terhadap cara kerja dan kinerja advokat yang dilakukan di Yogyakarta, Solo, Semarang, Pekalongan, Banyumas, dan Jakarta diperoleh data sebagai berikut. Di Yogyakarta sampai saat ini belum terbentuk Dewan Kehormatan Advokat Daerah apalagi Komisi Pengawas sehingga secara struktural keorganisasian, belum ada yang mengawasi advokat. Di Jawa Tengah, DPC Peradi berinisiatif menampung laporan atau pengaduan dari masyarakat atau advokat lain. Dari laporan itu kemudian akan diklarifikasi ke Dewan Kehormatan, jadi sifatnya hanya klarifikasi, bukan persidangan. Di Jawa Tengah juga belum ada Komisi Pengawas yang bertugas mengawasi advokat secara langsung. ${ }^{20}$

Oleh karena sifat pengawasan yang kurang maksimal dan hanya mengandalkan pada laporan atau pengaduan saja, maka jumlah atau statistik yang menunjukkan advokat bermasalah di Yogyakarta dan Jawa Tengah tercatat sedikit sekali. Akan tetapi hal ini jangan diterima sebagai kebenaran, karena berdasarkan penelusuran terhadap para informan, diperoleh data bahwa sebenarnya mereka tahu ada pelanggaran kode etik dalam pelaksanaan tugas pemberian jasa atau bantuan hukum oleh advokat, akan tetapi mereka enggan melaporkannya karena ada solidaritas sesama rekan sejawat. Beberapa pengaduan yang ada di Yogyakarta dapat diselesaikan melalui mediasi dan tidak sampai kepada Dewan Kehormatan Kode Etik Peradi, dan tentu saja yang menjadi cause célèbre dalam hal ini adalah kasus yang menimpa advokat yang memberi jasa hukum pada Probosutedjo. ${ }^{21}$

Berdasarkan hal tersebut, terlihat bahwa keinginan menggebu-gebu dari advokat untuk mempunyai lembaga pengawasan sendiri terle-

20 Agus Raharjo, Angkasa, and Hibnu Nugroho, Renewel on Monitoring the Performance of an Advocate as Efforts to Trial Making Clean and Respectable, Makalah pada Southeast Asia Legal Education: Preparing Lawyers for Tomorrow's Society and Profession, diselenggarakan oleh FH Unair dan School of Law University of Washington, Surabaya, 1-2 Oktober 2013, hlm. 10. 
pas dari pemerintah belum diikuti dengan langkah konkrit dari organisasi advokat. Alat kelengkapan lembaga pengawas belum semua hadir di daerah, sehingga pembiaran terjadinya pelanggaran kode etik masih dapat dijumpai. Perlu dilakukan langkah yang konkrit dari organisasi advokat agar ke depan Dewan Kehormatan dan Komisi Pengawas dapat terbentuk di semua daerah sehingga perkara-perkara yang ada di daerah dapat diselesaikan tanpa terhalang jarak dan waktu. ${ }^{22}$

Persoalan yang muncul dalam pengawasan advokat bukanlah persoalan yang bersifat tunggal yang dengan mudah dapat dicarikan solusinya. Bukan pula bersebab tunggal apabila ada advokat yang melakukan pelanggaran kode etik dalam menjalankan tugas profesinya, karena hal tersebut sebenarnya berkelindan dengan persoalan-persoalan yang ada dalam peradilan. Keinginan dari orang yang berkepentingan dalam penanganan suatu perkara (para pihak, polisi, jaksa, hakim, dan advokat) membentuk lingkaran setan yang melahirkan mafia peradilan. Selama lembaga pengawas tidak bisa menjangkau ruang dan waktu yang digunakan oleh mereka yang berkepentingan dalam penanganan suatu perkara maka selama itu pula pelanggaran kode etik akan terus terjadi. Dewan Kehormatan dan Lembaga Pengawas pada akhirnya akan tetap menjadi "macan ompong" seperti pada masa orde baru. Perlu dilakukan perombakan dalam mekanisme, cara kerja, dan penambahan wewenang pada lembaga pengawas agar menjadi lembaga yang berwibawa dan ditakuti oleh para advokat. ${ }^{23}$

Secara umum, pengawasan terhadap kinerja yang berkaitan dengan penegakan kode etik memang dilakukan oleh Organisasi Profesi melalui Komisi Pengawas. Akan tetapi terhadap advokat yang berpraktik mandiri, pengawasan secara internal tidak ada karena tidak mungkin mengawasi diri sendiri. Bagi advokat yang berpraktik di kantor hukum atau organisasi bantuan hukum, pengawasan terhadap kinerja mau pun penegakan kode etik dilakukan oleh atasan atau pimpinannya. Meski demikian, dapat saja

22 Ibid, hlm. 11

23 Ibid. terjadi pelanggaran kode etik yang merupakan hasil keputusan bersama antara advokat dan pimpinannya sehingga kesalahan yang dilakukan tidak lagi bersifat individual, tetapi juga organisasional. ${ }^{24}$

Pengawasan terhadap advokat yang bernaung di bawah kantor atau firma atau organisasi atau lembaga bantuan hukum berada di tangan atasan atau bagian dari institusi itu yang menangani pengawasan kinerja, akan tetapi siapakah yang mengawasi kinerja lembaga tersebut, Peradi misalnya, siapa yang mengawasi sepak terjangnya. Pertanyaan ini muncul mengingat independensi dari organisasi profesi ini tidak lagi berada di bawah bayang-bayang pemerintah.

Persoalan pengawasan terhadap kinerja organisasi atau lembaga profesi masih menimbulkan pertanyaan, akan tetapi dalam persoalan sebagaimana diamanatkan oleh UU No. 16 Tahun 2011 tentang Bantuan Hukum, Kantor Wilayah Hukum dan HAM Provinsi berhak mengawasi kinerja lembaga bantuan hukum yang menerima dana bantuan hukum, yaitu LBH atau $\mathrm{OBH}$ yang telah terakreditasi. Bentuk pengawasannya adalah melalui penyaluran dana bantuan hukum terhadap penanganan perkara yang dilakukan oleh LBH/OBH tersebut.

Apabila indikator kinerja menurut Kaplan diterapkan pada pengawasan kinerja advokat, maka pengawas yang paling berperan penting adalah atasan langsung advokat dan Kanwil Kemenhukham. Atasan langsung advokat merupakan atasan advokat yang diawasi dalam sebuah organisasi, sehingga hubungan kerja bersifat atasan bawahan. Pengawasan kinerja yang dapat dilakukan oleh atasan langsung berada pada indikator financial performance, internal business process, dan learning and growth. Kemudian pengawasan yang dilakukan oleh Kanwil Kemenhukham hanya pada financial performance, khusus pada advokat yang bernaung di bawah OBH penerima dana bantuan hukum.

Ada satu item yang belum ada pengawasan kinerja berdasarkan indikator yang diberikan oleh Kaplan, yaitu customer satisfaction.

24 Ibid, hlm. 10-11 
Siapakah yang bisa memberikan penilaian atas indikator ini, tidak lain dan tidak bukan adalah pengguna jasa, yaitu masyarakat. Sayang sekali dalam perundang-undangan yang disebut di atas, tidak ada satu pun yang memberikan peluang kepada masyarakat untuk melakukan pengawasan langsung kepada advokat. Kondisi ini menyebabkan perlunya dibuat saluran atau sistem dan wadah bagi masyarakat untuk bisa berpartisipasi dalam pengawasan kinerja advokat.

Sebagaimana disebut di atas, meskipun atasan langsung memiliki kewenangan dalam pengawasan atas kinerja advokatnya, pengawasan tersebut bersifat internal, sedangkan pengawasan eksternal atas kinerja advokat ataupun law firm atau law office yang terkait dengan financial performance misalnya tak terpublikasikan. Hal ini terlihat dari tidak adanya laporan keuangan atau neraca dari law firm atau law office yang dipublikasikan pada media cetak maupun elektronik.

Lemahnya pengawasan internal dan adanya esprit de corps dari sesama advokat menyebabkan sedikit sekali advokat yang tertangkap tangan atau dilaporkan oleh rekan sejawat ketika melakukan kejahatan maupun pelanggaran kode etik. Justru menjadi sebuah berita yang menghebohkan apabila ada advokat yang ditangkap oleh lembaga pengawas yang sebenarnya tidak berada pada garis depan pengawasan kinerja advokat. Masih segar dalam ingatan beberapa waktu yang lalu ada advokat yang ditangkap oleh KPK karena berupaya untuk melakukan suap kepada penyelenggara negara. Pada setiap kasus yang sedemikian, selalu dipertanyakan, kemanakah gerangan lembaga pengawasan advokat yang memiliki wewenang itu.

Advokat maupun $\mathrm{LBH} / \mathrm{OBH}$ dalam pelaksanaan pekerjaan mendampingi klien, juga diawasi oleh instansi/aparat penegak hukum di mana klien itu diperiksa atau disidik ataupun disidangkan. Polisi, Jaksa, Hakim, KPK, maupun lembaga lain yang memiliki Penyidik Pegawai Negeri Sipil mengawasi kinerja advokat. Sesuai dengan KUHAP, tugas advokat adalah membantu penegak hukum negara untuk menemukan kebenaran materiil, bukan mengaburkan kebenaran untuk keuntungan kliennya. Akan tetapi seringkali terjadi advokat justru melakukan upaya agar penemuan kebenaran materiil tidak berhasil, atau berhasil tetapi tidak maksimal sehingga pidana yang diberikan kepada kliennya bisa lebih ringan atau bahkan bebas sama sekali. Bahkan di tingkat penyidikan, advokat bisa menjadi partner yang baik dalam penyusunan Berita Acara Pemeriksaan (BAP), meskipun penyidikan dilakukan dengan kekerasan. ${ }^{25}$

Pengawasan kerja dan kinerja advokat seperti yang digambarkan di atas, masih memiliki kelemahan dan kekurangan yang perlu diperbaiki. Kebanyakan advokat yang berpraktik mandiri atau memiliki kantor sendiri dengan pengelolaan manajemen yang sederhana, bahkan dapat dikatakan tanpa manajemen agak sukar untuk mengukur kinerjanya. Hal ini disebabkan tidak adanya kontrol dari pihak eksternal yang mampu memberikan input bagi peningkatan kesadaran untuk selalu berusaha yang terbaik dalam kerjanya. Meski demikian, demi tegaknya hukum dan kembalinya marwah advokat yang officium nobile, pemberdayaan masyarakat dalam pengawasan advokat menjadi solusi yang perlu untuk dicoba.

\section{Penutup \\ Simpulan}

Berdasarkan uraian di atas, ada dua simpulan yang dapat dipetik. Pertama, advokat baik yang berpraktik mandiri atau bernaung di bawah law firm, law office maupun $\mathrm{OBH}$ - kurang memperhatikan indikator kinerja yang ada dalam ilmu ekonomi sebagai bagian dari cara untuk mengukur kinerja yang dilakukannya. Cara mengukur kinerja hanya bisa dilihat dari segi efektivitas penanganan perkara saja.

Kedua, advokat dan tempat bernaungnya mereka memiliki model pengawasan yang beragam, baik secara organisasi keprofesian (pengawasan internal) maupun yang berkaitan dengan bidang pekerjaan oleh instansi tertentu (pengawasan eksternal) yang bersinggungan dengan instansi tempat seorang advokat mendam-

25 Baca Agus Raharjo, Angkasa dan Hibnu Nugroho, "Rule Breaking dalam Penyidikan untuk Menghindari Kekerasan yang Dilakukan oleh Penyidik", Jurnal Dinamika Hukum Vol. 13 No. 1 Januari 2013, Purwokerto: FH UNSOED. 
pingi klien. Akan tetapi dari semua itu, pengawasan belum maksimal yang disebabkan masih ada esprit de corp dan pemakluman atas tindakan melanggar hukum yang dilakukan oleh advokat. Kondisi ini diperparah dengan belum berdirinya Komisi Pengawas dan Dewan Kehormatan Profesi di daerah-daerah.

\section{Saran}

Saran yang bisa diberikan untuk memecahkan permasalahan tersebut di atas adalah sebagai berikut. Pertama, para advokat perlu segera belajar ilmu ekonomi khususnya yang berkaitan dengan pengukuran kinerja melalui indikatornya. Law office atau law firm ataupun LBH/OBH segera menerapkan prinsip-prinsip manajemen agar proses birokrasi berperkara bisa lebih diukur efektivitas berdasarkan ukuran atau indikator yang secara objektif dapat diterima. Sudah saatnya pengelolaan organisasi yang bertumpu pada satu orang (single man) ditinggalkan dan diganti dengan profesionalisme dalam pengelolaan organisasi.

Kedua, perlu segera dibentuk Komisi Pengawas dan Dewan Kehormatan Profesi di daerah-daerah untuk mempercepat penanganan perkara-perkara yang berkaitan dengan pelanggaran etika. Pemberdayaan masyarakat juga perlu dilakukan mengingat mereka yang dirugikan akibat perilaku buruk advokat memiliki keengganan untuk melaporkannya pada organisasi tempat advokat itu bernaung. Perguruan tinggi tampaknya merupakan tempat yang cocok dan netral untuk menerima pengaduan dan meneruskannya pada instansi terkait.

\section{Daftar Pustaka}

Alkotsar, Artidjo. 2010. Peran dan Tantangan Advokat dalam Era Globalisasi. Yogyakarta: FH UII Press;

Amir, Ari Yusuf. 2008. Strategi Bisnis Jasa Advokat. Yogyakarta: Navila Idea;

Ananda, Suadarma. "Hukum dan Moralitas". Jurnal Hukum Pro Justitia Vol. 26 No. 3 Juli 2008;

Colares, Juscelino F. "The Evolving Domestic \& International Law Against Foreign Corruption: Some New \& Old Dilemmas Facing the International Lawyer. 5 Washington University Global Studies Law Review, 2006;

Fakrulloh, Zudan Arif. "Penegakan Hukum sebagai Peluang Menciptakan Keadilan". Jurisprudence, Vol. 2 No. 1 Maret 2005;

Kaplan, Robert S. \& David P. Norton. 1996. Translating Strategy Into Action The Balanced Scorecard. Boston-Massachu-setts: Harvard Business School Press;

Pekuwali, Umbu Lily. "Memposisikan Hukum sebagai Penyeimbang Kepentingan Masyarakat". Jurnal Hukum Pro Justitia Vol. 26 No. 4 Oktober 2008. Bandung: FH UNPAR;

Prawirosentono, Suyadi. 1997. Kebijakan Kinerja Karyawan (Manajemen Sumber Daya Manusia). Yogyakarta: Penerbit BPFE;

Rahardjo, Satjipto. "Hukum Progresif: Hukum yang Membebaskan". Jurnal Hukum Progresif Vol. 1 No. 1 April 2005. Semarang: PDIH UNDIP;

Raharjo, Agus. Angkasa dan Hibnu Nugroho. "Rule Breaking dalam Penyidikan untuk Menghindari Kekerasan yang Dilakukan oleh Penyidik". Jurnal Dinamika Hukum Vol. 13 No. 1 Januari 2013, Purwokerto: FH UNSOED;

Renewel on Monitoring the Performance of an Advocate as Efforts to Trial Making Clean and Respectable. Makalah pada Southeast Asia Legal Education: Preparing Lawyers for Tomorrow's Society and Profession, diselenggarakan oleh FH Unair dan School of Law University of Washington, Surabaya, 1-2 Oktober 2013;

Rajagukguk, Erman. "Advokat dan Pemberantasan Korupsi". Jurnal Hukum, Vol. 15 No. 3 Juli 2008. Yogyakarta: FH UII;

Rifai, Achmad. "Kedudukan dan Peran Advokat dalam Proses Penyelesaian Perkara Pidana". Jurnal Al-Ihkam, Vol. III No. 2 Desember 2008;

Rukmini, Mien. 2003. Perlindungan HAM Melalui Asas Praduga Tidak Bersalah dan Asas Persamaan Kedudukan dalam Hukum pada Sistem Peradilan Pidana Indonesia. Bandung: Alumni;

Suhardin, Yohanes. "Peranan Hukum dalam Mewujudkan Kesejahteraan Masyarakat". Jurnal Hukum Pro Justitia Vol. 25 No. 3 Juli 2008. Bandung: FH UNPAR; 
Ujan, Andre Ata. "Profesi: Sebuah Tinjauan Etis". Studia Philosophica et Theologica, Vol. 7 No. 2 Oktober 2007;

Widyastuti, A. Reni. "Penegakan Hukum: Mengubah Strategi dari Supremasi Hukum ke Mobilisasi Hukum untuk Mewujudkan Kesejahteraan dan Keadilan". Jurnal Hukum Pro Justitia Vol. 26 No. 3 Juli 2008. Bandung: FH UNPAR.

Wijayanta, Tata. "Bantuan Hukum Golongan Tidak Mampu dalam Perkara Perdata di Pengadilan Negeri Yogyakarta", Jurnal Mimbar Hukum Vol. 24 No. 1 Februari 2012. Yogyakarta: FH UGM;

Winarta, Frans Hendra. "Kedudukan Advokat atau Penasihat Hukum sebagai Penegak Hukum, Advokat atau Penasihat Hukum Menuju Undang-undang Profesi”. Majalah Hukum Pro Justitia Tahun XIV No. 4 Oktober 1996. Bandung: FH UNPAR;

-..-.-.. "Pencapaian Supremasi Hukum yang Beretika dan Bermoral". Jurnal Hukum Pro Justitia Tahun XX No. 1 Januari 2003. Bandung: FH UNPAR;

2009. Pro Bono Publico, Hak Konstitusional Fakir Miskin untuk Memperoleh Bantuan Hukum. Jakarta: Gramedia Pustaka Utama;

Yoserwan. "Model Sinkronisasi dan Koordinasi Pelaksanaan Tugas Aparat Penegak Hukum dalam Mewujudkan Sistem Peradilan Pidana Terpadu (Integrated Criminal Justice System)". Jurnal Hukum Respublica Vol. 7 No. 1 November 2007. Pekanbaru: FH Univ. Lancang Kuning. 